\title{
Communication
}

[Comunicação]

\section{Antimicrobial profile screening of two oils of Copaifera genus}

[Avaliação do perfil antimicrobiano de dois óleos do gênero Copaifera]

\author{
F.A. Pieri, V.O. Silva, C.F. Souza, J.C.M. Costa, L.F. Santos, M.A.S. Moreira*
}

Universidade Federal de Viçosa - Viçosa, MG

Copaiba trees are common to Latin America and West Africa being found in Brazil in the Southeast, Midwest, and Amazon. The exudate of these trees is a oil-resin, which has been used as a defense against parasites for over 500 years for many therapeutic purposes in Brazilian traditional popular and forestry medicine. Today it is one of the most important natural comercial products in North of Brazil and is exported to the United States, France, Germany and England (Veiga Junior and Pinto, 2002). This oil-resin is composed of a resinous fraction, consisting in diterpene acids, which is diluted in another essential oil composed of sesquiterpenes.

Among the main activities described for this medicinal oil are antimicrobial, antineoplasic, anti-inflammatory, and healing (Pieri et al., 2009). Several studies have been conducted to confirm these properties, including works about the potential for inhibition of bacterial growth and to establish its action spectrum. Gramnegative bacteria were presented as resistant to this phytotherapic in some works (Santos et al., 2008; Packer and Luz, 2007; Pacheco et al., 2006), and just one report showed data presenting sensibility (Mendonça and Onofre, 2009). Currently, the scientific literature has some reports of Gram-positive sensibility to copaiba oil (Pieri et al., 2010a; Pieri et al., 2010b; Mendonça and Onofre, 2009; Santos et al., 2008; Packer and Luz 2007; Pacheco et al. 2006). However there is still a need for further research to expand the available data and identify diseases and conditions where this oil could be used in microbial inhibitory treatment. We should also consider the species of copaiba studied, since there is a possible variability in the

Recebido em 1 de março de 2011

Aceito em 31 de novembro de 2011

*Autor para correspondência (corresponding author)

E-mail: masm@ufv.br oil components of different species and regions (Santos et al., 2008).

The objective of this study was to identify the inhibitory activity of copaiba oil obtained from two different species of Copaifera genus $(C$. langsdorffii and $C$. officinalis) against pathogenic bacteria of Human and Veterinary medicine.

It was performed an agar diffusion assay as described by Pieri et al. (2010b) with two copaiba oils solutions, one from $C$. langsdorffii tree and other from $C$. officinalis. These oils were solubilized with $10 \%$ Tween 80 , and both test solutions were prepared to a final concentration of $10 \%$ of copaiba oil. A solution of $10 \%$ Tween 80 was used as negative control. The test organisms included pathogenic bacteria, with interest to animal and human health, including: Gram-positive bacteria: four Staphylococcus aureus strains, ATCC 8095, 12598, 14458, 29213; and Gram-negative bacteria: Escherichia coli ATCC 11229, Pseudomonas aeruginosa ATCC 27853, Proteus mirabilis CDC 305, Klebsiella pneumoniae ATCC 13883, Shigella flexneri NCDC 9989, Citrobacter freundi ATCC 8090 and wild isolates of Actinobacillus pleuropneumoniae and Haemophilus parasuis. The clinical isolates of $H$. parasuis and A. pleuropneumoniae were incubated in jars under microaerophilic atmosphere, created with GasPak Plus (Becton, Dickinson and Company, Sparks, USA). The antimicrobial activity of each solution against bacterial isolates was identified by the presence or absence of inhibition halo and its diameter measurement. The data were analyzed by an ANOVA and compared with Tukey test. Significant results were considered with $\mathrm{P}<0,05$. 
The activity of the copaiba oils against bacteria is reported in Table 1. The results showed inhibition of three Gram-negative strains by both copaiba oil solutions: E. coli, P. aeruginosa and $S$. flexneri. For E. coli and S. flexneri, both oils had antimicrobial activity considered statistically equal, while for $P$. aeruginosa the $C$. officinalis oil was superior to $C$. langsdorffii, in relation to the diameters of the haloes $(\mathrm{P}<0.05)$. All strains of $S$. aureus were inhibited by the test solutions without statistic difference between the haloes.

Table 1. Inhibition haloes (in millimeters) obtained by copaiba oils from two different species and negative control against Gram-positive and Gram-negative bacteria

\begin{tabular}{lccc}
\hline Bacteria & C. langsdorffii & C. officinalis & Negative Control \\
\hline A. pleuropneumoniae (wild isolate) & 0 & 0 & 0 \\
C. freundii (ATCC 8090) & 0 & 0 & 0 \\
E. coli (ATCC 11229) & $17 \pm 0$ & $17.7 \pm 0.6$ & 0 \\
H. parasuis (wild isolate) & 0 & 0 & 0 \\
K. pneumoniae (ATCC 13883) & 0 & 0 & 0 \\
P. aeruginosa (ATCC 27853) & $18.7 \pm 0.6$ & $20.3 \pm 0.6$ & 0 \\
P. mirabilis (CDC 305) & 0 & 0 & 0 \\
S. flexneri (NCDC 9989) & $18.0 \pm 1.0$ & $17.7 \pm 0.6$ & 0 \\
S. aureus (ATCC 8095) & $14.7 \pm 1,2$ & $14,0 \pm 0$ & 0 \\
S. aureus (ATCC 12598) & $15.0 \pm 1.0$ & $14.0 \pm 0$ & 0 \\
S. aureus (ATCC 14458) & $15.7 \pm 0.6$ & $16.7 \pm 1.2$ & 0 \\
S. aureus (ATCC 29213) & $16.0 \pm 1.0$ & $18.0 \pm 1.0$ & 0 \\
\hline
\end{tabular}

Analyzing the sensitivity profile of the strains, $P$. aeruginosa was more sensitive, with haloes significantly higher than those of $E$. coli and all $S$. aureus strains $(\mathrm{P}<0.05)$, but without showing statistical differences to $S$. flexneri haloes. The latter and the strain of $E$. coli were more sensitive to the two oils when compared to two strains of $S$. aureus, ATCC 8095 and ATCC14458, which had smaller haloes $(\mathrm{P}<0.05)$. But there was no statistical difference between the strains of $S$. aureus.

Santos et al. (2008) verified resistance of $K$. pneumoniae and $P$. mirabilis to eigth copaiba oils (C. martii, C. officinalis, C. reticulata, $C$. langsdorffii, $C$. cearensis, $C$. paupera, $C$. multijjuga and $C$. lucens). The present data confirmed the resistance of these bacterial species in relation to both tested oils. However, in their research, no Gram-negative was inhibited by copaiba oils, including E. coli, S. flexneri and $P$. aeruginosa. In preview studies, Packer and Luz (2007) also observed no inhibition on the growth of ATCC strains of $E$. coli and $P$. aeruginosa using copaiba oil without the species designation and obtained commercially. Pacheco et al. (2006) tested eleven copaiba oils and also did not obtain inhibition of these species. In the present results, however, there was disagreement on these three bacterial species, which were inhibited by the two tested oils. Mendonça and
Onofre (2008) were the first to present data with inhibition of $E$. coli and $P$. aeruginosa by copaiba oil testing C. multijuga Hayne oil. The present work is the first report of inhibition of $S$. flexneri by copaiba oils.

It is suggested that these different results between all these studies have occurred in the diferent composition of oils, because they were obtained from different species of the genus Copaifera, or by factors such as different regions of extraction, collection time, climate and soils. There is also the possibility of different resistance profile of $E$. coli and $S$. flexneri strains tested with copaiba oil, whereas the ATCC bacteria tested were different in all cited researches and this antimicrobial protection feature is individual to each strain. However, to $P$. aeruginosa, the hypothesis of different compositions is more credible, since the strain tested by Santos et al. (2008) was the same used in the present work (ATCC 27853), and therefore it had the same genotypic and phenotypic characteristics, including resistance to antimicrobials. The C. officinalis oil presented, bacterial inhibition zone statistically higher than that of $C$. langsdorffii. There was no statistical difference between the oils when comparing the results for the other bacteria. 
Variation in chemical composition is common among different species and even among individual trees (PIERI et al., 2009). For example, oil-resins from $C$. reticulata collected in Acre and Pará states showed differences in activity against bacteria because of differences in chemical composition (Santos et al., 2008).

This is the first report of testing antimicrobial effect of copaiba oil against $A$. pleuropneumoniae, $C$. freundii and $H$. parasuis. Both tested oils showed incapacity to inhibit the growth of these bacterial species.

The results of $S$. aureus inhibition confirmed previous researches pointing sensitivity of this bacterium to this phytotherapic. Mendonça and Onofre (2009) showed inhibition of bacterial species by copaiba oil with filter paper disks impregnated with a solution of copaiba oil at a concentration of $1.56 \%$.

Santos et al. (2008) also obtained inhibition of two strains of $S$. aureus, one was a methicillinresistant, with all eight tested oils. This work also identified the inhibition of other Gram-positive bacteria as S. epidermidis, Bacillus subtilis and Enterococcus faecalis. The inhibition against $S$. aureus and B. subtilis was also described by Pacheco et al. (2006) in nine out of the eleven copaiba oils tested.

However, a work showed no inhibition by copaiba oil against S. aureus (Packer and Luz,
2007). Analyzing the known susceptibility of this species to copaiba oil, the authors suggest a possible degradation of the antimicrobial compounds present in oil as the reason for the absence of inhibition. Another reason could be the composition of this specific oil, which could have naturally smaller amounts of substances with activity against this bacterium.

Santos et al. (2008) points that copaiba oil may affect the cell wall, activity identified by electron microscopy of $S$. aureus challenged and not challenged with copaiba oil. However, it is suggested that beyond this action may still be compounds in the oil that act differently in the bacterial cell in view of the activity of the oils on Gram-negative bacteria revealed in the present research. This could result in a way to prevent or hinder the emergence of resistant bacteria, since the oil could contain different principles acting synergistically in various structures and mechanisms of bacterial cell.

In conclusion, the results of the present study suggest that copaiba oils may be potential sources of new and selective agents for the treatment of important infectious diseases, including those caused by Gram-negative and positive bacteria. Further laboratory and clinical studies of these oils are required in order to understand their antibacterial principles.

Keywords: phytotherapics, antimicrobial, antibacterial, Copaifera

\section{RESUMO}

O objetivo deste estudo foi identificar a atividade inibitória de óleos de copaíba sobre o crescimento dos micro-organismos: Shigella flexneri, Klebsiella pneumoniae, Escherichia coli, Proteus mirabilis, Pseudomonas aeruginosa, Citrobacter freundi, Staphylococcus aureus, Actinobacillus pleuropneumoniae e Haemophilus parasuis. Foi realizado um teste de difusão em ágar com duas soluções a $10 \%$ de óleos de copaíba obtidos de duas diferentes espécies de copaíba (Copaifera officinalis e C. langsdorffii) e um controle negativo com tween 80 e água. Os isolados clínicos de H. parasuis e A. pleuropneumoniae foram incubados em microaerofilia. Os resultados mostraram três espécies Gram-negativas inibidas por ambas as soluções de óleo de copaíba: E. coli, P. aeruginosa e S. flexneri. Na inibição de P. aeruginosa o óleo de $C$. officinalis foi superior ao de $C$. langsdorffii $(P<0,05)$. Todas as cepas de $S$. aureus tiveram seu crescimento inibido pelas soluções no ensaio, sem diferença estatística entre os halos. Estes resultados sugerem que o óleo de copaíba pode ser uma fonte potencial de compostos inibitórios para ser utilizada como antimicrobianos no tratamento de infecções humanas e animais e conservação de alimentos.

Palavras-chave: fitoterápicos, antimicrobianos, antibacterianos, Copaifera 


\section{AKNOWLEDGMENTS}

To FAPEMIG and CAPES for financial support.

\section{REFERENCES}

MENDONÇA, D.E.; ONOFRE, S.B. Atividade antimicrobiana do óleo-resina produzido pela copaiba - Copaifera multijuga Hayne (Leguminosae). Braz. J. Pharmacog., v.19, p.577-581, 2009.

PACHECO, T.A.; BARATA, L.E.; DUARTE, M.C. Antimicrobial activity of copaiba (Copaifera spp) balsams. Rev. Bras. Plantas Med., v.8, p.123-124, 2006.

PACKER, J.F.; LUZ M.M.S. Método para avaliação e pesquisa da atividade antimicrobiana de produtos de origem animal. Braz. J. Pharmacog., v.17, p.102-107, 2007.

PIERI, F.A.; MUSSI, M.C.M.; MOREIRA, M.A.S. Óleo de copaiba (Copaifera sp.): histórico, extração, aplicações industriais e propriedades medicinais. Rev. Bras. Plantas Med., v.11, p.465-472, 2009.
PIERI, F.A.; MUSSI, M.C.; FIORINI, J.E. et al. Efeitos clínicos e microbiológicos do óleo de copaíba (Copaifera officinalis) sobre bactérias formadoras de placa dental em cães. Arq. Bras. Med. Vet. Zootec., v.62, p.578-585, 2010a.

PIERI, F.A.; MANSUR, R. GALVÃO, N.N. $e t$ al. Antimicrobial activity of autoclaved and non autoclaved copaiba oil against Listeria monocytogenes. Cienc. Rural, v.40, p.17971781, 2010b.

SANTOS, A.O.; UEDA-NAKAMURA, T.; DIAS FILHO, B.P. et al. Antimicrobial activity of Brazilian copaiba oils obtained from different species of the Copaifera genus. Mem. Inst. Oswaldo Cruz, n.103, p.277-281, 2008.

VEIGA JUNIOR, V.F.; PINTO, A.C. O Gênero Copaifera L. Quim. Nova, v.25, p.273-286, 2002. 